\title{
Assessment of Genetic Variability, Heritability and Genetic Gain in Advanced Mutant Breeding Lines of Sesame (Sesamum indicum L.)
}

\author{
K. Divya ${ }^{1 *}$, T. Shobha Rani ${ }^{2}$, T. Kiran Babu ${ }^{3}$ and D. Padmaja ${ }^{4}$ \\ ${ }^{1}$ Department of Genetics and Plant Breeding, PJTSAU, College of Agriculture, \\ Rajendranagar, Hyderabad-500030, Telangana, India \\ ${ }^{2}$ Plant Breeding, PJTSAU, Agricultural Research Station, Nathanaipally, Medak-502110, \\ Telangana, India \\ ${ }^{3}$ Plant pathology, AICRP on Sesame, Regional Agricultural Research Station, Polasa, \\ Jagtial-505529, Telangana, India \\ ${ }^{4}$ Plant Breeding, Rice Research Scheme, Regional Agricultural Research Station, Polasa, \\ Jagtial-505529, Telangana, India \\ *Corresponding author
}

\begin{tabular}{|c|}
\hline Keywords \\
\hline $\begin{array}{l}\text { PCV, GCV, } \\
\text { heritability, GAM, } \\
\text { mutant breeding } \\
\text { lines, diseases }\end{array}$ \\
\hline Article Info \\
\hline $\begin{array}{l}\text { Accepted: } \\
18 \text { May } 2018 \\
\text { Available Online: } \\
\text { 10 June } 2018\end{array}$ \\
\hline
\end{tabular}

A B S T R A C T

In present investigation, 133genotypes comprised of advanced mutant breeding lines, germplasm lines, genotypes pertaining to Initial Varietal Trial, Advanced varietal Trial and Multi Location Trial, popular varieties national, zonal and local checks were evaluated for assessment of genetic variability at Regional Agricultural Research Station, Jagtial with Randomized Block design in 3 replications. Influence on breeding programmes is especially based on the extent to which variability occurs and the relative amount of variation in the different traits. It is measured by determining the genotypic coefficient of variance (GCV) and phenotypic coefficient of variance (PCV). Since heritability may be affected by environmental factors, information of predicted genetic gain will be more helpful in the selection process. Genetic advance (GA) on the other hand refers to the improvement of traits in genotypic value for the new population in comparison with the original population. From the above investigated material, the highest GCV and PCV was observed for traits seed yield per plant followed by number of capsules per plant, number of branches per plant and phyllody (\% incidence). The heritability estimates were high for days to maturity followed by days to $50 \%$ flowering, plant height, seed yield per plant, number of branches per plant, number of capsules per plant and phyllody (\% incidence). High heritability coupled with high GAM indicates the presence of additive gene action for the characters and they are inherited through simple selection. 


\section{Introduction}

In the country oilseeds sector occupies an important position contributing to the Gross Domestic Product. In India, sesame is being grown over an area of 19.50 lakh hectares with production of 8.50 lakh tonnes and productivity of $436 \quad \mathrm{~kg} / \mathrm{ha}$ (www.indiastat.com, 2016). In Telangana, it is grown over an area of 0.14 lakh hectares with an annual production of 0.03 lakh tonnes and productivity of $214 \mathrm{~kg} / \mathrm{ha}$ (www.indiasta.com, 2016). Major sesame growing states in India are West Bengal, Madhya Pradesh, Uttar Pradesh, Punjab and Gujarat.

In Telangana state, it is grown as summer crop in Jagtial, Nizamabad, Nirmal, Adilabad, Karimnagar, Khammam, Asifabad and Mahaboobnagar etc. It is called the "Queen of Oilseeds" and is also known as 'benni seed', 'gingelly', 'simsim', 'til' etc. and is the oldest and an ancient oil seed crop known to man. Africa is considered the primary centre of origin, while, India and Japan are considered as the two secondary centers of origin of this crop. India, China, Sudan, Mexico, Turkey, Burma and Pakistan are the important sesame producing countries. Sesame seed contains 50$60 \%$ oil and $19-25 \%$ protein with two lignans i.e., sesamin and sesamolin, which prevent rancidity and give sesame oil a long shelf life (Ashakumary et al., 1999). Sesame has been given less attention by the farmers because of poor yield due to non-availability of cultivars to suit the diverse agro-climatic conditions.

Creation of newer variation for morphological, yield and yield attributing traits is possible through germplasm augmentation, hybridization and mutation breeding. Yield being a complex character, is collectively influenced by various component characters, which is polygenically inherited and subjected to environmental variation. Critical analysis of genetic variability present in the germplasm of a crop and its estimation is a pre-requisite for initiating any crop improvement programme as well as adopting appropriate selection techniques and helps breeding of high yielding and good quality cultivars that will increase production. Heritability indicates the extent of transmissibility of a character into future generations. It is very difficult to judge whether observed variability is heritable or non-heritable. Hence, the knowledge of heritability is also essential for selection of component traits for yield improvement. Genetic advance measures the difference between the mean genotypic values of selected population and the original population from which these were selected. In the light of above facts, this study was planned with objective of estimating genetic variability.

\section{Materials and Methods}

The present investigation for estimation of genetic variability was carried out with 133genotypes including national check (TKG22), Zonal check (Pragathi) and Local check (Swethatil) during kharif, 2017 at Regional Agricultural Research Station, Polasa, Jagtial. The characterization site is located at $18^{\circ} 48^{i} \mathrm{~N}$ latitude, $78^{\circ} 56 \mathrm{E}$ longitude and about $281 \mathrm{~m}$ altitude of mean sea level . It has annual rainfall of $901 \mathrm{~mm}$ per year and average temperature $27.6^{\circ} \mathrm{C}$. The material was grown at this site in 2 rows of $2 \mathrm{~m}$ long with interrow spacing of $30 \mathrm{~cm}$ and intra-row spacing of $10 \mathrm{~cm}$. The experiment was laid out in Randomized Block Design (RBD) with three replications during kharif, 2017. All the standard package of practices was followed during crop growth period. Observations were recorded on the basis of five random competitive plants selected from genotypes in every replication for seed yield and its attributing characters and disease parameters. WINDOSTAT statistical package was used for analysis. The genotypic, phenotypic variance, heritability and genetic advance as 
per cent mean was calculated as per the formulae given by Burton and de Vane (1953) and Jonhson et al., (1955).

\section{Results and Discussion}

Seed yield is a complex trait, polygenic and highly influenced by environmental conditions. A successful breeding programme depends upon the genetic variability present among the different genotypes. Phenotypic selection of parents for hybrids based only on their performance alone may not always be available procedure since phenotypically superior genotypes may yield inferior hybrids and/or poor recombinants in the segregating generations. It is therefore essential that parents are selected on the basis of their genetic worth, that is, heritability along with genetic advance are both important for selection (Hamouda et al., 2016).

The mean sum of squares for yield and yield attributing traits i.e., days to 50per cent flowering, days to maturity, plant height, number of branches per plant, number of capsules per plant, test weight, seed yield per plantalong with the disease parameters Alternaria leaf spot, phyllody and Cercospora leaf spot were presented in Table 1. Among all the traits highest variance is observed for phyllody (1401.92) followed by plant height (898.37). This indicates 133 genotypes of sesame were studied to assess their genetic potential exhibited highest variability for phyllody followed by plant height.

The mean sum of squares was highly significant for days to 50 per cent flowering, days to maturity, plant height, number of branches per plant, number of capsules per plant, seed yield per plant, Alternaria PDI, phyllody (per cent incidence) and Cercospora PDI were highly significant. While for test weight it is non-significant. All the genotypes displayed considerable amount of differences in their mean performance with respect to all the traits studied, which indicates that the genotypes under study were genetically diverse.

An assessment of heritable and non-heritable components in the total variability observed was indispensable in adopting suitable breeding procedure. The heritable portion of the overall observed variation can be ascertained by studying the components of variation such as coefficients of genotypic and phenotypic variability, heritability and predicted genetic advance. The range, mean, phenotypic and genotypic coefficients of variability, heritability estimates in broad sense and genetic advance as per cent of mean for the above parameters is presented in Table 2 . The phenotypic and genotypic coefficient of variation was represented in Fig.1 whereas heritability and genetic advance as per cent of mean were represented in Fig.2.All the sesame genotypes exhibited a significant amount of variability (PCV and GCV) for all the yield and yield contributing characters and disease parameters i.e., days to 50 per cent flowering, days to maturity, plant height, number of branches per plant, number of capsules per plant, seed yield per plant, Alternaria PDI, phyllody (per cent incidence) and Cercospora PDI were evidenced significant by " $F$ " test at $p(0.01)$ level of significance. This type of wide range of variation provides ample scope of selection for desired genotypes and further improvement.

\section{Days to 50 per cent flowering:}

Overall mean for days to 50 per cent flowering was seen as 53.26 days with a wide variation between the earliest 38.33 days and late 69.33 days.188 RK was earliest to flower while 50KRE8-1was late followed by 30KRDS-1-2. This wide range of variation for days to 50 per cent flowering is in line with observations of earlier workers such as Jadhav and Mohrir 
(2012). Genotypic and phenotypic coefficients of variation were moderate with 13.13 and 13.31 per cent respectively. These results were supported by Vanishree et al., (2013). This wide range of variation provides shifting the seasonal timing of reproduction and produce novel varieties that are better adopted to local environment and change in climatic conditions. This character had high heritability (97.22\%) with genetic advance (14.20) and high genetic advance per cent of mean of 26.67\% (Anitha and Manivannan, 2014) High heritability and GAM suggested that this character is predominantly controlled by complex gene interaction and this also indicated importance of additive genetic effects for control of this character.

\section{Days to maturity}

Maturity duration varied from 71.33 days to 113.33 days with mean of85.22 days. Advanced breeding line10KRE8-1, 188 RK and CPD local-2016 matured early while Rajeswari matured late. Low genotypic and phenotypic coefficients of variation were observed (9.01 and $9.11 \%$ respectively) and also reported by Sumathi and Muralidharan (2010). Variation in days to maturity provides ample scope for selection of early and late maturing plants for further improvement. This trait has recorded high heritability (97.76\%) coupled with genetic advance (15.65). The per cent mean of genetic advance was moderate $(18.36 \%)$ similar to the results given by Monpara (2016). High heritability and moderate GAM of this trait indicated that environmental control of the character.

\section{Plant height (cm)}

Plant height varied from47.20to $132.70 \mathrm{~cm}$ with an overall mean of $94.68 \mathrm{~cm}$. Among all the genotypes30KRDS-1-14 (47.20) was dwarf, while AT-332(132.70) was the tallest. Genotypic and phenotypic coefficients of variation were 17.80 and 19.18 per cent respectively which were moderate. Thirumala Rao et al., (2013) also confirmed the same results. This trait exhibited high heritability (86.2 \%) with expected genetic advance (32.24). The per cent mean of genetic advance was also high $(34.05 \%)$. This trait is having similar results given by Sandipan et al., (2010). This trait is governed by complex gene interaction important for control of additive genetic effects for the control of this character which indicates response to selection.

\section{Number of branches per plant}

Number of branches varied from 1.66 to 8.00 with overall mean of 4.93 branches per plant. 82 RK, 162 RK were single branching type, while SDSN-15-16 is profuse branching type. High genotypic and phenotypic coefficients of variation 28.01 and 33.05 per cent respectively were recorded are collinear with results given by Gayatree et al., (2011). Presence of high variability for genotypes evaluated facilitates genetic improvement. This trait recorded high heritability $(71.8 \%)$ with genetic advance (2.41). The per cent mean of genetic advance was high with $48.90 \%$ (Sandipan et al., 2010). Results indicated possible scope for improvement through selection of this character and breeder may have reliable benefits in next generation with respect to this character.

\section{Number of capsules per plant}

Range of variation from 6.00 to 61.00 was observed for capsules per plant with an overall mean of 19.31 capsules per plant.II IBL Local (1), II IBL Local (7) and TKG-22(6) produced very less number of capsules, whileSDSN-1514 had more number of capsules (61) per plant. Genotypic and phenotypic coefficients of variation were high i.e., 50.72 and 53.69 per cent respectively. Similar are given by Sumathi and Muralidharan, (2010). 
Fig.1 Genotypic and phenotypic coefficients of variation for yield and yield attributing traits in sesame genotypes at RARS, Jagtial during kharif, 2017

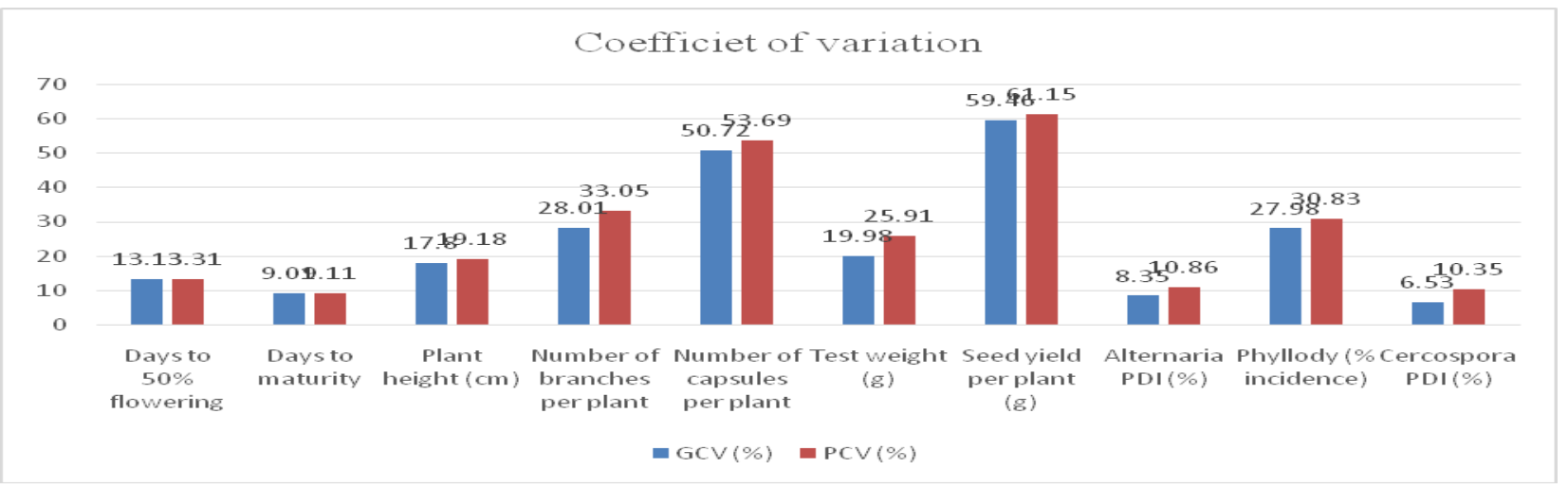

Fig.2 Heritibility and Genetic advance as per cent of mean for yield and yield attributing traits in sesame genotypes at RARS, Jagtial during kharif, 2017

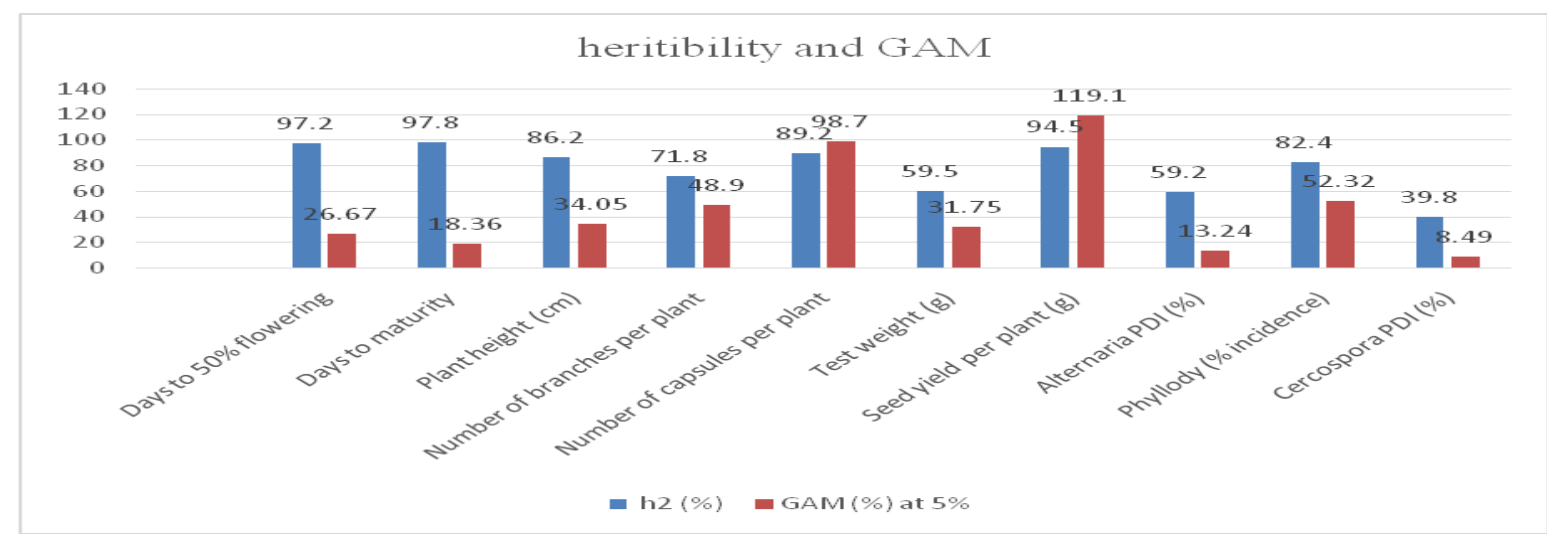

Table.1 Analysis of Variance for yield and yield attributing traits in sesame at RARS, Polasa, Jagtial during kharif, 2017

\begin{tabular}{|c|c|c|c|c|}
\hline \multirow[t]{2}{*}{ S. No. } & \multirow[t]{2}{*}{ Character } & \multicolumn{3}{|c|}{ Mean Sum of Squares } \\
\hline & & $\begin{array}{l}\text { Replications } \\
(\mathbf{d f}=2)\end{array}$ & $\begin{array}{l}\text { Genotypes } \\
(\mathbf{d f}=132)\end{array}$ & Error $(d f=264)$ \\
\hline 1. & Days to $50 \%$ Flowering & 1.10 & $148.15^{* *}$ & 1.39 \\
\hline 2. & Days to Maturity & 1.31 & $178.38 * *$ & 1.35 \\
\hline 3. & Plant Height $(\mathrm{cm}$ & 52.36 & $178.38 * *$ & 45.59 \\
\hline 4. & Number of Branches per Plant & 2.21 & $6.49 * *$ & 0.75 \\
\hline 5. & Number of Capsules per Plant & 2.92 & $299.47 * *$ & 11.57 \\
\hline 6. & Test weight (g) & 0.20 & 0.73 & 0.13 \\
\hline 7. & Seed yield per Plant (g) & 0.42 & $8.21 * *$ & 0.15 \\
\hline 8. & Alternaria leaf spot PDI (\%) & 8.72 & $204.24 * *$ & 38.19 \\
\hline 9. & Phyllody (\% incidence) & 276.68 & $1401.92 * *$ & 93.21 \\
\hline 10. & Cercospora leaf spot PDI (\%) & 145.46 & $170.13 * *$ & 56.96 \\
\hline
\end{tabular}


Table.2 Genetic parameters for yield and yield attributing traits in sesame at RARS, Polasa, Jagtial during kharif, 2017

\begin{tabular}{|c|c|c|c|c|c|c|c|c|c|c|}
\hline \multirow[t]{2}{*}{ Trait } & \multicolumn{2}{|c|}{ Range } & \multirow[t]{2}{*}{ Mean \pm SD } & \multicolumn{2}{|c|}{ Variance } & \multicolumn{2}{|c|}{$\begin{array}{c}\text { Coefficient of } \\
\text { Variation }\end{array}$} & \multirow[t]{2}{*}{$\begin{array}{l}h^{2} \\
(\%)\end{array}$} & \multirow{2}{*}{$\begin{array}{c}\text { Genetic } \\
\text { Advance } \\
\text { (GA) at } \\
\mathbf{5 \%}\end{array}$} & \multirow{2}{*}{$\begin{array}{c}\text { GAM } \\
(\%) \text { at } \\
5 \%\end{array}$} \\
\hline & $\min$ & $\max$ & & Genotypic & Phenotypic & GCV (\%) & PCV (\%) & & & \\
\hline $\begin{array}{l}\text { Days to } 50 \text { per } \\
\text { cent flowering }\end{array}$ & 38.33 & 69.33 & $53.26 \pm \mathbf{0 . 6 8}$ & 48.92 & 50.31 & 13.13 & 13.31 & 97.22 & 14.20 & 26.67 \\
\hline $\begin{array}{l}\text { Days to } \\
\text { maturity }\end{array}$ & 71.33 & 113.33 & $85.22 \pm \mathbf{0 . 6 6}$ & 59.01 & 60.36 & 9.01 & 9.11 & 97.76 & 15.65 & 18.36 \\
\hline $\begin{array}{l}\text { Plant height } \\
(\mathrm{cm})\end{array}$ & 47.20 & 132.70 & $94.68 \pm \mathbf{3 . 8 8}$ & 284.26 & 329.85 & 17.80 & 19.18 & 86.18 & 32.24 & 34.05 \\
\hline $\begin{array}{l}\text { Number of } \\
\text { branches per } \\
\text { plant } \\
\end{array}$ & 1.66 & 8.00 & $4.93 \pm \mathbf{0 . 4 9}$ & 0.91 & 2.66 & 28.01 & 33.05 & 71.81 & 2.41 & 48.90 \\
\hline $\begin{array}{l}\text { Number of } \\
\text { capsules per } \\
\text { plant }\end{array}$ & 6.00 & 61.00 & $19.31 \pm \mathbf{1 . 9 5}$ & 95.96 & 107.54 & 50.72 & 53.69 & 89.24 & 19.06 & 98.70 \\
\hline Test weight (g) & 1.04 & 3.23 & $2.22 \pm \mathbf{0 . 2 1}$ & 0.19 & 0.33 & 19.98 & 25.91 & 59.48 & 0.70 & 31.75 \\
\hline $\begin{array}{l}\text { Seed yield per } \\
\text { plant (g) }\end{array}$ & 0.26 & 9.40 & $2.75 \pm \mathbf{0 . 2 2}$ & 2.68 & 2.84 & 59.46 & 61.15 & 94.54 & 3.28 & 119.10 \\
\hline $\begin{array}{l}\text { Alternaria leaf } \\
\text { spot PDI }(\%)\end{array}$ & 56.66 & 100.00 & $89.03 \pm \mathbf{3 . 5 5}$ & 55.35 & 93.54 & 8.35 & 10.86 & 59.17 & 11.79 & 13.24 \\
\hline $\begin{array}{l}\text { Phyllody (\% } \\
\text { incidence) }\end{array}$ & 6.33 & 100.00 & $74.63 \pm 5.55$ & 436.23 & 259.45 & 27.98 & 30.83 & 82.39 & 39.05 & 52.32 \\
\hline $\begin{array}{l}\text { Cercospora } \\
\text { leaf spot PDI } \\
(\%)\end{array}$ & 63.33 & 100.00 & $93.98 \pm \mathbf{4 . 3 4}$ & 37.72 & 94.69 & 6.53 & 10.35 & 39.84 & 7.86 & 8.49 \\
\hline
\end{tabular}


This trait recorded high heritability $(89.24 \%)$ with genetic advance of 19.06 . The per cent mean of genetic advance was also high (98.70 \%) (Bharathi et al., 2014). Presence of high heritability and GAM for this trait reveals the additive gene effect and can be effectively used in selection procedure.

\section{Test weight (g)}

The average test weight was $2.22 \mathrm{~g}$ with a range varying from 1.04 to $3.23 \mathrm{~g} .30 \mathrm{KRDS}-1$ 26had lighter seeds (1.04g) while DS-46had recorded heavier seed (3.23g).Moderate genotypic coefficient of variation $(19.98 \%)$ and high phenotypic coefficient of variation $(25.91 \%)$ were observed. The same results are recorded by Bharathi et al., (2014). This trait recorded moderate heritability $(59.5 \%)$ with genetic advance (0.70) and the per cent mean of genetic advance was high $(31.75 \%)$. The results are similar with Rajani Bisen et al., (2013). This trait is controlled by dominant genes and can be improved through heterosis breeding.

\section{Seed yield per plant (g)}

Seed yield per plant exhibited a wide amount of variation varying from 0.26 to $9.40 \mathrm{~g}$ per plant. The overall mean was $2.75 \mathrm{~g}$. II IBL Local (5) was poor seed yielder $(0.26 \mathrm{~g})$, while YLM-66 recorded maximum seed yield per plant $(9.40 \mathrm{~g})$.The genotypic and phenotypic coefficients of variation were 59.46 and 61.15 per cent which were moderate and high respectively (Abate et al., 2015). The heritability was high (94.54\%) withgenetic advance (3.28). The per cent mean of genetic advance was high (119.10\%) (Tripathy et al., 2016). Though seed yield was influenced by yield contributing characters high heritability and GAM indicates, this trait is controlled by additive gene effect and phenotypic selection of this character would fasten the varietal improvement period.

\section{Alternaria PDI (Per cent Disease Index)}

The overall mean for the Alternaria disease is $89.03 \%$. The variation exhibited by the genotypes is between 56.66 and 100.00 percent.TKG-506is recorded low (56.66) while, JCS-2698, Swethatil@, SDSN-15-14, Mall-1is recorded highest (100.00). The genotypic and phenotypic coefficients of variation were low (8.35) and moderate (10.86) per cent respectively for Alternaria PDI. These results are in conformity by Shobha Rani and Ravi Kumar, (2002) in sunflower. The heritability was moderate $(59.17 \%)$ with genetic advance (11.79). The per cent mean of genetic advance was moderate $(13.24 \%)$. The same results are recorded by Sujatha and Nadaf, (2013) in onion. This parameter is controlled both by additive and dominant gene effects which can be improved by recurrent selection.

\section{Phyllody (\% incidence)}

For Phyllody (per cent incidence) overall mean observed was 74.63. The variation exhibited by the genotypes is between 6.33 and 100.00.SDSN-15-98 is recorded low (6.33) while II IBL Local (5) and SDSN-1572 is recorded highest (100.00). The genotypic and phenotypic coefficients of variation were 27.98 and 30.83 per cent respectively which were high. The heritability (82.39per cent) and the per cent mean of genetic advance were high $(52.32 \%)$. The genetic advance of the disease is 39.05.High heritability and GAM of this trait indicates that it is less controlled by environment and additive gene action plays important role which reveals response to selection is high.

\section{Cercospora PDI (Per cent Disease Index)}

Cercospora disease is one of the important foliar diseases, the overall mean observed was 93.98 percent. The variation exhibited by the 
genotypes is between 63.33 and 100.00 per cent. YLM-11 was recorded low $(63.33 \%)$ while 50 KRE8-1, 30 KRDS-1-6, 30 KRDS1-18, 30 KRDS-1-71, 60 KRE8-1-4, 60 KRE8-1-5, RS Black, RS I Black, RS Black 108 and N-8 were recorded highest (100.00\%) PDI. The genotypic and phenotypic coefficients of variation were low $(6.53 \%)$ and moderate $(10.35 \%)$ respectively. Moderate GCV was reported by Kumari (2008) and Adama et al., (2017) in ground nut. The heritability was moderate $(39.84 \%)$ coupled with the low per cent mean of genetic advance ( $8.49 \%)$. Moderate heritability coupled with low GAM emphasises that this parameter is highly influenced by environment and controlled by both additive and dominant gene effects. This parameter may be improved by heterosis breeding.

In the present study high PCV observed for all the parameters reveals the influence of environment on the manifestation of these parameters. Hence the difference between PCV and GCV was high for test weight (5.93) followed by number of branches per plant (5.04), number of capsules per plant (2.97), seed yield per plant (1.69) and plant height (1.38). This indicates test weight and number of branches per plant were influenced more by environment followed by seed yield per plant and plant height compared to other yield and yield contributing traits. This study also reveals days to 50 per cent flowering and days to maturity were least effected by environment.

An estimated heritability values alone is less reliable as these values are prone to alter with change in the environment and experimental material (Swarup and Chaugle., 1962). Hence, the use of high heritability coupled with high genetic advance is preferred and observed only for days to 50 per cent flowering, plant height, number of branches per plant, number of capsules per plant and seed yield. Thus, these traits are most probably controlled by additive gene action which may respond to selection. Among disease parameters, high heritability coupled with high GAM was observed for phyllody and moderate was observed for Alternaria PDI and Cercospora PDI.

Wide range of variation is present among the genotypes which is high for characters number of branches per plant, number of capsules per plant, seed yield per plant and phyllody (\% incidence). This magnitude of variation provides ample scope of selection for desired genotypes and further improvement. High heritability coupled with high genetic advance as per cent ofmean was observed for days to $50 \%$ flowering, plant height, number of branches per plant, number of capsules per plant, seed yield per plant and phyllody (\% incidence) suggesting that, these characters were controlled by additive gene action. These are inherent characters and could be improved by simple phenotypic selection. Moderate heritability associated with low GAM was observed for test weight which suggests the role of dominant gene action and can be improved using heterosis breeding.

\section{Acknowledgment}

Professor Jayashankar Telangana State Agriculture University for providing stiphend during the study period.

Regional Argricultural Research Station, Polasa, Jagtial for providing site for conducting the experiment.

\section{References}

Abate, M., Mekbib, F., Ayana, A., and Nigussie, M. 2015. Genetic variability and association of traits in mid-altitude sesame (Sesamum indicum L.) 
germplasm of Ethiopia. Am. J. Exp. Agr. 9(3): 1-14.

Adama, Z., Abel, T.N., Sawadogo, M., Konate, A.K., Sankara, P., Ntare, B.R., and Desmae, H. 2017. Variability and correlation among groundnut population for early leaf spot, pod yield and agronomic traits. Agronomy (Madison). 7: 52-63.

Anitha, B.K., and Manivannan, N. 2014. Variability studies in $\mathrm{M}_{2}$ of sesame (Sesamum indicum L.). Int. J. Trop. Agric. 32(2): 43-45.

Ashakumary, L., Rouyer, I., Takahashi, Y., Ide, T., Fukuda, N., Aoyama, T., Hashimoto, T., Mizugaki, M., and Sugano, M. 1999. Sesamin, a sesame lignan, is a potent inducer of hepatic fatty acid oxidation in the rat. Metab. Clin. Exp. 48(10): 1303-1313.

Bharathi, D., Thirumala Rao, V., Mohan, Y.C., Bhadru, D., and Venkanna, V. 2014. Genetic variability studies in sesame (Sesamum indicum L.). Int. J. Appl. Biol. Pharm. 5 (4): 31-33

Burton, G.W., and de Vane, E.H. 1953. Estimating heritability in Tall Fescue (Festuca arundinacea) from replicated clonal material. Agron. J. 45: 481-487.

Gayatree, G.S., Lokesha, R., Vasudevan. N., and Naik, M.K. 2011. Phenotypic characterization of $\mathrm{F}_{3}$ progenies and inheritance study on phyllody in sesame (Sesamum indicum L.). Plant Archieves. 11(2). 875-877.

Hamouda, F.E., Bashirand, S.G.E., and Ginaro, M.K. 2016. Phenotypic and genotypic coefficients of variation and other growth attributes in sesame genotype under rain-fed conditions. Adv. Agric. Agric. Sci. 2(3): 79-84.

https://www.indiastat.com, 2016.

Jadhav, R.S., and Mohrir, M.N. 2012. Genetic variability studies for quantitative traits in sesame (Sesamum indicum L.).
Electron. J. Plant Breed. 3(4): 10091011.

Johnson*, H.W., Robinson, H.F., and Comstock, R.E. 1955. Estimates of genetic and environmental variability in soybean. Agron. J. 47: 314-318.

Kumari, V. 2008. Morphological and molecular characterization of induced mutations in groundnut. M. Sc. Thesis. University of Agricultural Sciences, Dharwad, India.

Monpara, B.A., 2016. Sesame germplasm evaluation for reproductive period and harvest index. Genetika. 48(2): 665674.

Rajani Bisen., Tripathi, A., Ravindra P.A., Paroha, S., Sahu, R., and Ranganatha. A.R.G. 2013. Study on genetic divergence in sesame (Sesamum indicum L.) germplasm based on morphological and quality traits. The Bio-Scan. 8(4): 1387-1391.

Sandipan, C., Datta, A.K., Saha, A., Sengupta, S., Paul, R., Maity, S., and Das, A. 2010. Traits influencing yield in sesame (Sesamum indicum L.) and multilocational trials of yield parameters in some desirable plant types. Indian J. Sci. Technol. 3(2):163166.

Shobharani, T., and Ravikumar, R.L. 2002. Evaluation of $F_{1}$ progenies from populations tolerant to Alternaria blight in sunflower. Crop Res. 24(1): 77-80.

Sujatha, K., and Nadaf, H.L. 2013. Genetic studies on Alternaria leaf spot disease resistance and yield component traits in sunflower. M. Sc. Thesis. University of Agricultural Sciences, Dharwad, India.

Sumathi, P., and Muralidharan, V. 2010. Analysis of genetic variability, association and path analysis in the hybrids of sesame (Sesamum indicum L.). Tropical Agric. Res. Ext. 13(3): 6367. 
Swarup, S., and Chaugle, B.S. 1962. Studies on genetic variability in Sorghum; phenotypic variation and heritable component in some quantitative characters contributing towards yield. Indian J. Genet. Pl. Breed. 22: 31-36.

Thirumala Rao, V., Bharathi, D., Chandra Mohan, Y., Venkanna, V., and Bhadru, D. 2013. Genetic variability and association analysis in sesame (Sesamum indicum L.). Crop Res. 46 (1, 2 \& 3): 122-125.

Tripathy, S.K., Mishra, D.R., Panda, S., Senapati, N., Nayak, P.K., Dash, G.B.,
Mohanty, S.K., Mohanty, M.R., Jena, M., and Pradhan, K. 2016. Assessment of genetic variability in sesamum (Sesamum indicum L.). Asian Journal of Science and Technology. 7(2): 24822485.

Vanishree, Lokesha, R., Goudappagoudr, R., and Chetankumar, N.B. 2013. Analysis of genetic variability for yield and its components in sesame (Sesamum indicum L.). Int. J. Plant Sci. 8(1): 9193.

\section{How to cite this article:}

Divya K., T. Shobha Rani, T. Kiran Babu and Padmaja, D. 2018. Assessment of Genetic Variability, Heritability and Genetic Gain in Advanced Mutant Breeding Lines of Sesame (Sesamum indicum L.). Int.J.Curr.Microbiol.App.Sci. 7(06): 1565-1574.

doi: https://doi.org/10.20546/ijcmas.2018.706.187 